\title{
Цветелина Георгиева
}

Институт за български език при БАН София

\section{Неологизми със суфикс -[a]джий(a) в българския език}

Имената за лица са значителна част от неологизмите в българския език. В настоящото изследване интересът е насочен към онези от тях, които са образувани с турския по произход суфикс -[а]джий(а) и илюстрират (ре)активизацията на форманта. Статията има за цел да установи преди всичко към кои словообразувателни категории се отнасят новите деривати, кои словообразувателни типове са най-продуктивни, има ли изменение по отношение на произвеждащата основа (по-нататьк ПщО), с която контактува формантът -[а]джий(а) и в какви синонимни отношения влизат новите деривати.

Известно е, че още преди няколко века -джий(а) (с вариант след шумови съгласни -чий(a) < от турски -ci / -çi) е станал словообразувателен формант (по-нататък СФ) в българския език, с който се създават съществителни имена за лица - срв. а̀йкаджия [Геров I: 6], ключарджия [Геров II: 377], писаджйя [Геров IV: 33], потѐраджия [Геров IV: 238], свирджиेя ${ }^{1}$. В някои

1 Трябва да се отбележи, че формантът проявява активност и в българската диалектна система. Така например с него са образувани названия като момарджйя, навалджйя, сговорджйя, тъкменджиेя и др. - всичките със значение 'сватовник' [вж. БСРЛ 2012]. 
случаи затруднението при словопроизводството на дериватите се преодолява чрез добавяне на асемантема -а- към суфиксалния морф, в резултат на което се получава разширеният вариант -аджий(а).

В лингвистичната литература обикновено се посочва, че суфиксът се свързва със субстантивни основи, но трябва да се отбележи, че в миналото са се образували, макар и рядко, производни думи от глаголни основи (вж. примерите по-горе). Възможно е също и създаването на деадвербиални производни, напр. гратисчия 'някой, който пътува или посещава нещо (обикн. представление) гратис 'безплатно”.

През 40-те години на XX в. Л. Андрейчин посочва, че самата наставка служи за „означаване на лица според предмети, които са свързани съ тъхъ чрезъ тьхното занятие или въ другъ нъкакъвъ смисълъ” [Андрейчин 1944: 92-93] и освен това „тая наставка може да означава и особеность на характера” [Андрейчин 1944: 94]. В Граматиката си Л. Андрейчин твърди, че наставката се присъединява само към основи на съществителни имена. Не е случаен подборът на илюстративния материал. Явно е желанието на езиковеда да отрази „различните значения” на наставката -джия ${ }^{2}$ в съчетание с една и съща произвеждаща основа - „кафеджия 'някой, който прави кафе' и кафеджия ‘някой, който обича кафе"” (пак там).

По-различен е подходът при описанието на имената с -джѝя / -чѝя в единствената засега българска академична граматика, излязла в началото на 80-те години на миналия век ${ }^{3}$. Според Ст. Стоянов (автор на раздела) съществителните имена (а не суфиксът - бел. моя, Ц. Г.) „назовават деятелни лица според тяхната професия, специалност или някоя отличителна особеност" [Граматика 1983: 55]. В труда се отбелязва, че

2 В статията се придържаме към начина на изписване на суфикса в съответните трудове.

3 В [Граматика 1983] наставката е изписана с ударение. Известно е обаче, че ударението е присъщо на лексикалната единица като цяло, а не на отделни нейни части. Освен това при повечето посочени деривати коренната морфема е под ударение, е не суфиксът (срв. изброените там примери шегаджѝя, моза̀йкаджия, дво̀йкаджия, кйбладжия, ловджй, цйркаджия, гра̀тисчия и др. - вж. [Граматика 1983: 55]; при заемките ударението също се запазва върху суфикса - изкл. прави пра̀нгаджия).

Няколко години по-късно В. Радева извежда следното правило: „наставките -джий(а) и -чий(а) винаги са под ударение”, а „съществителните, образувани с разширена наставка -аджий(а), запазват ударението върху основата си", напр.: біудаджия, дво̀йкаджия, ка̀ртаджия, содаджия, пло̀чкаджия, ийркаджия [Радева 1991: 103]. Като изключение от посоченото по-горе акцентно правило може да се приведат стари и нови имена като шегаджиेя, комп'ютьрджия, форрумджия. 
наставката има висока продуктивност и влиза в контакт както с чужди, така и с домашни основи, без да се уточнява каква е тяхната лексикограматична характеристика.

В студията си „Морфологична адаптация и асимилация на турските заемки - съществителни и прилагателни - в българския език” Кювлиева посочва, че на българска почва -джия се свързва с основи на съществителни и рядко на прилагателни ${ }^{4}$ и глаголи и образува както деятелни имена за лица от м.p. (nomina agentis), така и деривати в рамките на nomina attributiva, които назовават лица по техен признак, напр. участие в реакционни политически акции и особености на характера. Авторката споделя разбирането на В. Маскимов за словообразувателен тип (което е различно от мнението на М. Докулил, В. Лопатин, И. Улуханов и др.) и обединява в един тип производни с -джия, образувани от основи на съществителни, прилагателни и глаголи, като определя и семантични подтипове. Според Кювлиева -джия заема първо място сред наставките в българския език, с които се образуват имена за лица [вж. Кювлиева 1980: 117].

По-различно е виждането на Радева относно дериватите на -джий(а) / -чий(а). Като изхожда от ономасиологичната теория на М. Докулил, изследователката разглежда имената за лица в рамките на словообразувателната категория nomina actoris и ги класифицира в три групи: 1) лица, характеризирани според професионален признак (напр. гайтанджия, мозайкаджия и др.); 2) лица, характеризирани в зависимост от названието на мястото, посочено като характеризиращ признак на деятелно отношение (пощзаджия, циркаджия и др.) и 3) лица, назовани според характерна особеност или склонност към дадена дейност и проява (напр. гуляйджия, скандалджия и др.) ${ }^{5}$. Според В. Радева „съществителните, оформени

${ }^{4}$ Най-вероятно авторката има предвид производните скъпчия и евтинджия [вж. Кювлиева 1980: 115]. Наистина, във външната структура на дериватите присъства компонент, който съвпада по форма с прилагателните скъn и евтин, но словообразувателните парафази - 'някой, който продава нещо или прави нещо (някаква услуга) скъпо' и 'някой, който продава нещо или прави нещо (някаква услуга) евтино' - показват друга мотивация - от наречията скъпо и евтино.

5 Наред с домашните образувания като nomina actoris ca посочените и преки заемки от турски (напр. абаджия, бюрекчия, сахатчия и др.), явно поради факта, че тяхната произвеждаща основа съществува като самостоятелна лексема в българския език (за срв. - у Н. Геров лексеми като бостанджия, кавгаджия, мандраджия, механджия са посочени като заемки от турски език - вж. [Геров I, II, III]).

В хода на изследването бяха направени справки и с речници на чуждите думи. Установи се, че в „Речника на чуждите думи...” на Ст. Буров и П. Пехливанова [РЧД 1995] лексема будкаджия - производна дума от будка [последната е навлязла у нас от немски 
с разглежданите наставки, са присъщи предимно на разговорния език” [Радева 1991: 103] и са създадени само от субстантивни основи.

Според Аврамова обаче суфиксът -(a)джиј(а) изгражда съществителни не от една, а от няколко словообразувателни категории (по-нататък СК) - nomina agentis ${ }^{6}$, nomina disponentis, nomina pertinentia, nomina attributiva и nomina experiencer [вж. Аврамова 2003: 125]. Авторката установява, че през изследвания от нея период (края на XX в.) не се създават нови единици с дистрибутивния вариант -чиј(a), а образуваните деривати със СФ -(а)джиј(а) са десубстантивни.

В настоящото изследване се споделя мнението, изказано от някои езиковеди [вж. напр. Димитрова 1962; Балтова 1976; Аврамова 2003 и др.], че отименните деятелни лица са подобни на отглаголните деятелни имена, тъй като изразяват действие, макар и неексплицитно. Това е причина и двата вида сыществителни, назоваващи деятели, да се разглеждат като деривати от словообразувателната категория nomina agentis. В този смисъл десубстантивните деятелни имена с турския по произход суфикс се определят като производни от категорията nomina agentis.

Неологизмите с формант -[а]джий(а) ${ }^{7}$, ексцерпирани от два лексикографски труда - „Речник на новите думи и значения в българския език” [РНД 2001] и „Речник на новите думи в българския език” [РНД 2010], тук са представени по словообразувателни категории (а в рамките на nomina agentis и по лексикосемантични групи) ${ }^{8}$. При анализа на дериватите се отчита времето на тяхната поява и отразяване в лексикографските трудове: от 1990 до 2000 год. - деривати, ексцерпирани от [РНД 2001], от 2001 до 2010 - деривати, ексцерпирани от [РНД 2010] ${ }^{9}$. Въз основа на посочените парафрази се предлага и вътрешнокатегориално диференциране. Наличието на две семеми при някои деривати налага условното им разграничаване чрез цифровите маркери (1) и (2), поставени след

през руски] - присъства със самостоятелна речникова статия, макар че не е заемка [?!]. В словника на същия речник откриваме и производната даракчия [вж. РЧД 1995: 81, 124]. Тези факти пораждат въпроса имат ли място в речници на чуждите думи деривати, които са създадени в домашни условия от основи на чужди лексеми.

6 В. Радева определя дериватите от тази категория като nomina actoris.

7 През изследвания период не са образувани деривати с-чий(a).

8 В настоящото изследване се споделя в общи линии изложеното от Цв. Аврамова мнение относно съдържанието на СК - вж. [Аврамова 2003: 24-29].

9 Лексемите ${ }^{\star}$ каналджия, *модаджия, *чалгаджия и др. под. няма да бъдат обект на анализ тук, тъй като те не са новосъздадени деривати. Причина за включването им в словника на двата речника е тяхното ново значение, което е отразено чрез звездичка. 
лексемата, напр. пицаджия (1) 'някой, който продава пици' и пицаджия (2) 'някой, който прави пици' (и двете принадлежат към nomina agentis); рападжия (1) 'някой, който изпълнява рап(музика)' и рападжия (2) 'някой, който обича рап(музиката)' (nomina agentis и nomina experiencer).

Неологизмите $\mathrm{c}$-[a]джий $(\mathrm{a})^{10}$, създадени в българския език през последните две десетилетия, принадлежат към шест словообразувателни категории. Предлага се обобщена парафраза (по-нататък ОП) на дериватите, включени в СК, а самите деривати са представени с техните конкретни парафрази.

\section{Nomina agentis}

Неологизмите от тази СК принадлежат към една от петте посочени по-долу лексикосемантични групи.

1. Като първа се определя групата съществителни, които назовават деятел в зависимост от обекта на действие. Те имат ОП 'някой, който действа върху нещо/работи по нещо'.

От 1990 до 2000 год. се създават дериватите:

байкаджия 'някой, който кара байк', компютғрджия 'някой, който поправя / продава компютри', маршруткаджия 'някой, който кара маршрутка', рапанджия 'някой, който лови рапани', скрападжия 'някой, който събира скрап', таксиджия 'някой, който кара такси', таксиметраджия 'някой, който кара таксиметрова кола'.

От 2001 до 2010 год. се създават дериватите:

бордаджия ' 'някой, който кара борд (спортен уред)', гумаджия 'някой, който сменя гуми', джипаджия 'някой, който кара джип', патентаджия 'някой, който плаща патентен данък', патрулкаджия 'някой, който кара патрулка `патрулен автомобил”, рафтаджия 'някой, който кара рафт', спамаджия 'някой, който изпраща спам(ове по интернет)'.

Въз основа на конкретните словообразувателни парафрази се налага изводът, че дериватите имат за произвеждащи основи както съществителни, така и съчетание от прилагателно + съществително име, като само първата част от него е експлицирана (вж. таксиметраджия, патентаджия). Мотивиращите думи означават конкретни предмети.

10 В изследването се приема този начин на изписване, за да се обхванат всички варианти на суфикса - без и с разширение [a] - и да се разграничи самият суфикс от окончанието (а). 
2. Като втора група може да се посочат съществителните, които назовават деятел в зависимост от резултата от някакво действие. Тяхната ОП е 'някой, който прави (създава, произвежда) нещо'.

От 1990 до 2000 год. се създават дериватите:

гафаджия 'някой, който прави често гафове', дюнерджия 'някой, който прави дюнери', компроматаджия 'някой, който прави често компромати', попаджия (1) 'някой, който изпълнява поп(музика)', рападжия (1) 'някой, който изпълнява рап(музика)', рокаджия (1) 'някой, който изпълнява рок(музика)', уейфаджия (1) 'някой, който изпълнява (ню)уейф(музика)', фолкаджия (1) 'някой, който изпълнява фолк(музика)', хардрокаджия (1) 'някой, който изпълнява хардрок(музика)'.

От 2001 до 2010 год. се създават дериватите:

графитаджия 'някой, който рисува графити', наколенкаджия 'някой, който прави наколенки', пирамидаджия 'някой, който участва в създаване на *пирамида 'финансова пирамида', пищаджия 'някой, който прави пици', попфолкаджия (1) 'някой, който изпълнява попфолк(музика)', рекламаджия 'някой, който създава, проектира реклами', сайтаджия 'някой, който създава, проектира сайтове', салатаджия 'някой, който прави салати', халтураджия 'някой, който създава халтура 'нискокачествени произведения', хитаджия 'някой, който създава или изпълнява хитове', хороскопаджия 'някой, който прави хороскопи'.

Неологизмите имат за ПщО само субстантиви. Прави впечатление, че във формалната структура на деривата уейбаджия присъства в ськратен вид неговата ПщО. Сред мотивиращите думи има един неосемантизъм ( ${ }^{*}$ пирамида > пирамидаджия).

Неологизмите съдържат допълнителен признак 'може, умее, професионално извършва дадено действие’.

3. Трета група са съществителните, които назовават деятел в зависимост от предмета на дейност. Те имат ОП 'някой, който се занимава с нещо, практикува нещо, участва в нещо'.

От 1990 до 2000 год. се създават дериватите:

бингаджия 'някой, който играе на бинго', биткаджия 'някой, който участва в битка (в сбиване, в бой)', брейкаджия 'някой, който танцува брейк', митингаджия 'някой, който участва в митинги', перестройкаджия 'някой, който участва в перестройката', хазартаджия 'някой, който играе хазарт', чатаджия 'някой, който участва в чат', щортттрекаджия 'някой, който упражнява шорттрек ${ }^{\prime 1}$.

От 2001 до 2010 год. се създават дериватите:

11 Тук не се посочва дериватът антибомбаджия 'някой, който участва в борбата срещу бомб(ения тероризъм)', тъй като той е конфиксално образувание. 
агиткаджия 'някой, който участва в агитка', пиараджия 'някой, който се занимава с пиар', форумджия 'някой, който участва във форум'.

Неологизмите са десубстантивни деривати. Повечето от мотивиращите единици са от чужд произход.

За този тип производни Балтова посочва, че имат общ конотативен признак 'може, умее, професионално извършва определено действие' [вж. Балтова 2007: 97].

4. Четвърта група са съществителните, които назовават деятел в зависимост от средството за действие. Тяхната ОП е 'някой, който си служи с нещо, използва нещо'.

От 1990 до 2000 год. се създават дериватите:

балонджия 'някой, който лети с балон', брбмбарджия 'някой, който използва / монитира *бръмбари 'вид подслушвателни устройства с микрофон` за нещо', бутерджия 'някой, който приготвя нещо (храна) от бутер(тесто)', бухалкаджия 'някой, който прави нещо (прилага насилие върху някого) с помощта на бухалка', взломаджия 'някой, който извършва нещо (кражба) чрез взлом', гриладжия 'някой, който приготвя нещо (храна) на грил', интернетаджия 'някой, който прави нещо, като използва Интернет', нетаджия 'някой, който прави нещо, като използва нет'.

От 2001 до 2010 год. се създават дериватите:

мутраджия 'някой, който прави нещо (обикн. рекет), като използва * мутрата си 'едрия си външен вид и агресивното си поведение', порбчкаджия 'някой, който прави нещо (нападение, убийство и др.), като изпълнява поръчка', скараджия 'някой, който приготвя нещо (храна) на скара', торентаджия 'някой, който прави нещо (споделя файлове с някого), като използва торенти'.

И при тази група суфиксът -[а]джий(а) влиза в контакт само със субстантивни основи. Сред производните също има деривати, чиято ПщО е семантичен неологизъм (брбмбарджия, мутраджия), а във формалната структура на бутерджия ПщО присъства в съкратен вид.

5. Пета група са съществителните, които назовават деятел в зависимост от мястото на действие. Те имат ОП 'някой, който действа (работи) някъде'.

От 1990 до 2000 год. се създават дериватите:

бензинджия (1) 'някой, който работи на бензин(останция)', битакаджия 'някой, който търгува на битака', косаджия 'някой, който работи в КОС [кос] - (служба) Контрол на общоопасните средства', магистраладжия 'някой, който търгува по магистрали (по пътищата)', палаткаджия 'някой, който живее на палатка', румнаджия 'някой, който работи в РУМНО [румно] - Разузнавателно управление на Министерството на народната отбрана', сотаджия 'някой, който работи 
в СОТ [сот] - Сигнално-охранителна техника', чейнджаджия (1) 'някой, който работи в чейндж (чейнжбюро)'.

От 2001 до 2010 год. се създават дериватите:

бопаджия 'някой, който работи в (НС)БОП [(несе)боп] - Национална служба за борба с организираната престъпност', дансаджия 'някой, който работи в ДАНС [данс] - Държавна агенция „Национална сигурност”, кабелджия (1) 'някой, който работи в *кабел 'кабелна телевизия'.

Неологизмите са десубстантивни. По-голяма част от дериватите имат за ПщО лексоид ${ }^{12}$ (напр. косаджия, дансаджия). Във формалната структура на производната бензинджия присъства само първият компонент на произвеждащия композитум.

\section{Nomina experiencer}

СК обединява названия за лица, които имат предразположение, склонност към нещо, проявяват привързаност, изпитват някакви чувства към нещо ${ }^{13}$. Производните имат ОП 'някой, който обича нещо, има склонност към нещо'.

От 1990 до 2000 год. се създават дериватите:

дрогаджия 'някой, който обича дрогата', купонджия 'някой, който обича купоните', попаджия (2) 'някой, който обича поп(музиката)', рападжия (2) 'някой, който обича рап(музиката)', рокаджия (2) 'някой, който обича рок(музиката)', хардрокаджия (2) 'някой, който обича хардрок(музиката)'.

От 2001 до 2010 год. се създават дериватите:

попфолкаджия (2) 'някой, който обича попфолк(музиката)', спагетаджия 'някой, който обича спагетите', уейфаджия (2) 'някой, който обича (ню)уейф(музиката)', фолкаджия (2) 'някой, който обича фолк(музиката)'.

Създадените неологизми са десубстантивни. Дериватите са предимно от областта на музиката.

12 Лексоидът е особен вид номинационна езикова единица, която е вторична по отношение на някакво графемно съчетание (напр. ВИС, КОС, СОТ, ГЕРБ, СПИН, SIC и др.), съществува обикновено само в разговорната реч като цялостен звуков комплекс със собствено ударение, има граматичен род и (понякога) форми за число и може (или е потенциално възможно) да се членува. Лексоидът тук е представен в скоби, напр. [вис], [кос] и т.н. Приема се, че той има характеристика на субстантив. Повече по въпроса вж. [Георгиева 2012a].

13 По-различно е виждането на Цв. Аврамова за лицата, които са привърженици на нещо. Авторката ги включва в СК nomina pertinentia [Аврамова 2003]. 


\section{Nomina pertinentia}

СК обединява имена за лица, които принадлежат към някаква общност. Понякога в семантиката на дериватите се съдържа и признакът 'агентивност', но той остава на заден план [вж. още Аврамова 2003: 78]. Производните думи имат ОП 'някой, който е член и/или привърженик на нещо (партия, движение, организация или др.)'.

От 1990 до 2000 год. се създават дериватите:

висаджия 'някой, който е член и/или привърженик на ВИС(-2) [вис] - Застрахователна компания по името на основателя Васил Илиев и Security', мултигрупаджия 'някой, който е член на „Мултигруп”, нисаджия 'някой, който е член на НИС [нис] - Национален изпълнителен съвет', подкрепаджия 'някой, който е член и/или привърженик на (Конфедерацията на труда) „Подкрепа”, сикаджия 'някой, който е член на СИК [сик] - Security Insurance Company', хайлайфаджия 'някой, който принадлежи към хайлайфа'.

От 2001 до 2010 год. се създават дериватите:

атакаджия 'някой, който е член и/или привърженик на партия „Атака”, бордаджия ' 'някой, който е член на борд (на директорите)', гербаджия 'някой, който е член и/или привърженик на ГЕРБ [герб] - Граждани за европейско развитие на България', семаджия 'някой, който е член на CEM [сем] - Съвет за електронни медии'.

Създадените неологизми също са десубстантивни. Половината деривати имат за произвеждаща основа лексоид.

Неологизмите принадлежат към обществено-политическата лексика. Част от тях вече са загубили своята актуалност поради отмиране на реалиите.

\section{Nomina disponentis}

СК обединява имена за лица, притежатели на нещо. Съответно и тяхната ОП е 'някой, който притежава нещо'. В езика са създадени само пет деривата: бензинджия (2) 'някой, който притежава бензин(останция)', кабелджия (2) 'някой, който притежава *кабел 'кабелна телевизия', мобифонаджия 'някой, който притежава мобифон', фирмаджия 'някой, който притежава фирма', чейнджаджия (2) 'някой, който притежава чейндж(бюро)'.

Неологизмите са създадени през първия период (до 2001 г.) и имат за ПщО субстантиви. 


\section{Nomina attributiva}

СК обединява названия за лица, които се характеризират чрез някакво качество, характеризират се с някакъв постоянен, вътрешноприсъщ признак. Създадени са два деривата с ОП 'някой, който е носител на определено качество'. Производните са випаджия 'някой, който е ВИП [вип] - Very Important Person' и хардкораджия 'някой, който е хардкор (страстен участник в нещо или почитател на нещо)', съответно образувани през първия и втори период. Производните са десубстантивни. Чуждите по произход произвеждащи основи са нови за българския език.

\section{Nomina patientis}

Към СК nomina patientis се отнасят съществителни, които назовават лица, подложени на някакво (въз)действие. Тяхната ОП е 'някой, който търпи нещо'. В тази група съществителни се сключват и имена за лица, които страдат от някаква болест ${ }^{14}$. Единственият създаден дериват е спинаджия 'някой, който е болен от СПИН [спин] - Синдром на придобитата имунна недостатъчност', чиято произвеждаща основа е лексоид. Неологизмът принадлежи към първия разглеждан период.

Новите названия за лица със суфикс-[а]джий(a) са отименни деривати, като значително по-голяма част от дериватите са десубстантивни. Като новост в българския език може да се посочи създаването на производни с ПщО съчетание от адектив + субстантив, от което само адективният компонент е експлициран (патентаджия, таксиметраджия).

За разлика от производните до 80-те години на XX в., за които е характерно свързването на суфикса с основата без помощта на гласна [a] [вж. Кювлиева 1980: 116], през последните двайсет години повечето неологизми са образувани с разширения вариант на СФ -аджий(а).

Най-многобройни са названията от nomina agentis, следвани от nomina experiencer, nomina pertinentia, nomina disponentis, nomina attributiva и nomina patientis. Прави впечатление, че след 2001 г. няма създадени имена за лица от категорите nomina disponentis и nomina patientis.

Асимилираният от българската словообразувателна система суфикс -[а]джий(a) продължава да проявява широки съчетателни възможности.

14 Цв. Аврамова ги разглежда като специфична група в рамките на nomina attributiva [Аврамова 2003: 28]. 
И в най-ново време той се свързва с произвеждащи основи от домашен и чужд произход. При повечето от посочените по-горе деривати формантът -[а]джий(а) се съчетава на българска почва с относително нова чужда субстантивна произвеждаща основа, най-често от английски произход, напр.: байк- + -аджий(a), брейк- + -аджий(a), Интернет- + -аджий(a), pan- + -аджий(a), paфm- + -аджий(a), caŭm- + -аджий(a), скраn+ -аджий(a), сnам- + -аджий(a), хит- + -аджий(a), чейндж- + -аджий(a), чат - + -аджий(a), шорттрек- + -аджий(а) и др. В повечето случаи почти успоредно с навлизането на чуждата дума или създаването на домашно образувание (напр. универбат, абревиатура) се появяват и деривати с формант -[а]джий(a), което е доказателство за продуктивността на словообразувателния модел (срв. още маршрутка $\rightarrow$ маршруткаджия, ГЕРБ [герб] $\rightarrow$ гербаджия и др.). Макар и по-рядко, като мотивираща единица за образуване на дериватите служи лексема, която е вече утвърдена в българския език и е станала „своя”, напр. балонджия ${ }^{15}$.

Както вече беше посочено по-горе, някои от произвеждащите лексеми са семантични неологизми, срв. *брбмбар 'вид подсушвателно устройство с микрофон' (РНД 2001: 49) > брғмбарджия [РНД 2001], * кабел 'кабелна телевизия' [РНД 2001: 126] > кабелджия [РНД 2001], * купон 'забавление, празненство, обикн. с участие на много хора' [РНД 2001: 149] > купонджия [РНД 2001], * мутра 'лице от силовите групировки и организираната престъпност, което се занимава обикн. с принудително застраховане, рекет и др. и парадира с луксозен начина на живот' [РНД 2001: 178] > мyтраджия [РНД 2010], *наколенка 'прояви на угодничене, раболепничене, подмазване с цел домогване до благоразположението, протекцията на някого' [РНД 2001: 180] > наколенкаджия [РНД 2010], * пирамида 'финансова структура, привличаща вложители с обещание за по-високи лихви, които всъщност са парично необезпечени и зависят от набирането на все повече нови депозити, използвани за изплащане на лихви само на първите вложители, така че като резултат банката фалира' [РНД 2001: 284] > пирамидаджия, * форум 'рубрика в сайт или отделен сайт, където потребителите публикуват съобщения със свои мнения по определена тематика' [РНД 2010: 474] > форумджия [РНД 2010]. Както се вижда, обик-

15 Интересен е случаят на деривация, при който се наблюдава прескок на една словообразувателна стъпка. Така например ПщО на магистраладжийка е магистрала, а не магистраладжия (в езика засега не съществува такава лексема). Има пилонаджийка < пилон, но няма пилонаджия. Има създадени деривати ченгеджийнии, ченгеджийски, ченгеджийничество, ченгеджийство, но няма ченгеджия (има обаче ченгесар). 
новено успоредно с появата на новия семантизъм се образува и дериват със суфикс -[а]джий(а). Изключение правят създадените през първото десетилетие на XXI в. производни мутраджия и наколенкаджия, чиито произвеждащи основи са семантични неологизми от края на XX в.

Още преди 80-те години на XX век в българския език се появява нов модел имена за лица, при който дериватите са образувани по инициална абревиатура, т.е. от лексоид + суфикс (срв. тираджия, катаджия и др.). По този модел се образуват деривати и в най-ново време. Като домашни може да се определят следните лексоидни основи, с които се създават нови имена за лица: [6оn] (НС)БОП '(Национална служба за) борба с организираната престьпност' > бопаджия, [герб] ГЕРБ 'Граждани за европейско развитие на България' > гербаджия, [данс] ДАНС 'Държавна агенция Нащионална сигурност' > дансаджия, [кос] КОС '(служба) Контрол на общоопасните средства' > косаджия, [спин] СПИН 'Синдром на придобитата имунна недостатъчност’ > спинаджия и др. При лексоида [nuap] се наблюдава приспособяване на изговора на чуждоезичната инициална абревиатура PR към българската морфологична система и по-точно към категорията на съществителното име. При този лексоид процесът на лексикализация е завършил и той се среща в писмени текстове и като пиар.

Всичко това дава основание произвеждащите основи на дериватите със СФ -[а]джий(а) условно да се разделят на две групи:

1) от обикновен (традиционен) тип, напр. агиткаджия < агитка, байкаджия < байк, дюнерджия < дюнер, купонджия < купон, пииаджия < пииа, сайтаджия < сайт, спамаджия < спам, бирмаджия < фирма, хазартаджия < хазарт, хардрокаджия < хардрок и др.

и 2) от лексоиден тип, напр. гербаджия < [герб] ГЕРБ 'Граждани за европейско развитие на България', дансаджия < [данс] ДАНС 'Държавна агенция Национална сигурност', семаджия < [сем] СЕМ 'Съвет за електронни медии', сотаджия < [com] СОТ 'Сигнално-охранителна техника' и др.

Трябва да се отбележи, че процесът на образуване на имената за лица с произвеждаща единица лексоид е особено активен през последните 20 години. Едно бъдещо изследване на новите имена за лица в българския език, би могло да определи мястото на този словообразувателен модел в общата езикова картина.

Разгледаните неологизми влизат в синонимни отношения с еднословни (и рядко с многословни) названия. Някои от дериватите с формант -[a] джий(а) имат повече от един синонимен корелат, срв. байкаджия = байкър; бордаджия = бордист, бордовик, бордовак, бордьр; брейкаджия = брейкар; гербаджия = гербист, гербовак, гербер; дрогаджия = наркоман; мутраджия = 
мутра, бореи, дебел врат, дебеловрат; наколенкаджия = угодник, подмазвач, блюдолизеи, наколенка; палаткаджия = палаткар; перестройкаджия = перестройчик; пиараджия = пиар, пиармен, пресаташе; попаджия = попьр; рападжия = рапьр; рекламаджия = рекламист; спагетаджия = италианеи; спамаджия = спамгр; форумджия = форумеи, форумист; хитаджия - хитмайстор, хитмейкър, чатаджия = чатьр и др. Начините и пътищата за създаване на синонимните корелати са различни. Така например, въпреки че някои от смисловите еквиваленти на лексемите с-[а]джий(а) имат същия корен, не всички са домашни образувания - срв. английските заемки байкър, бордър, попьр, рапьр, спамър, хитмейкър, чатьр, пиар, пиармен и съответните еднокоренни деривати с разглеждания суфикс. Новосъздадените езикови единици демонстрират как -[а]джий(а) съответства по значение не само на суфикси, които не са СФ в българския език, но и на суфикси, които са продуктивни в езика ни (-ец, -ист, -овик, -ак, -ар и др.). Синонимният ред гербаджия, гербист, гербовак, гербер привлича вниманието, защото съдържа четири лексеми, които имат семантична връзка с политическата партия ГЕРБ, но са продукт на различни деривационни процеси - първите три са резултат от морфологично словообразуване, докато гербер е резултат от асоциативно словообразуване ${ }^{16}$.

Друга синонимна двойка, която привлича вниманието, е дрогаджия - наркоман. За разлика от субстантива дрогаджия, създаден чрез суфиксация, смисловият му еднословен еквивалент наркоман ('някой, който е болен от наркомания') е резултат от парадигматична деривация.

Обикновено в лингвистичната литература се посочва, че дериватите с формант -[а]джий(a) се характеризират с разговорност, поради което в лексикографската литература с тях се тълкуват други разговорни езикови единици (напр. атакист с атакаджия, бордовак и бордовик с бордаджия такстист с таксиджия, брейкър с брейкаджия и др.). През последните години обаче се наблюдава процес на стилистична неутрализация на дериватите със СФ -[а]джий(a). Донякъде тази теза се потвърждава и от факта, че в РНД 2010 деривати, завършващи на -[а]джий(а), са посочени като равностойни синоними на заемки или домашни образувания, които са:

16 В българския език има имена за лица със завършек -ер, които се съотнасят с по-елементарни в структурно и семантично отношение единици (срв. напр. касиер и каса, комбайнер и комбайн, магазинер и магазин, фермер и ферма, снайперист и снайпер). Въпреки това, отчитайки екстралингвистичните и лингвистичните факти, приемаме, че при образуването на названието за лице гербер стои формалната аналогия с популярното в българския език име на растението Gerbera jamesonii (гербер), а завършекът -ер вторично може да се разглежда като афикс - вж. по въпроса [Георгиева 20126]. 
- стилистично неутрални (байкаджия - байкър, графитаджия - графитист);

- терминологични единици (бордаджия ${ }^{2}$ - бордист (спорт.), рападжия - рапғр (муз.), рабтаджия - рабтьр (спорт.), рекламаджия - рекламист (рекл.), форумджия - форумеи (информ.), форумист (информ.) и др.).

В речниците има дори деривати със суфикс -[а]джий(a), при които липсва бележка разг. (дюнерджия, чалгаджия).

В заключение може да се посочи, че неологизмите с формант -[а]джий(a) са $30 \%$ от общия брой суфиксалните имена за лица в българския език, образувани през последните 20 години (преди тях са само дериватите със суфикс -ист). Те се появяват не само за да задоволят нуждата от назоваване на понятия, за които няма еднословна езикова единица, но вероятно и като реакция срещу множеството навлезли чужди (предимно английски) думи в българския език. Донякъде новосъздадените имена за лица издават стремежа на българина да говори „по нашенски”, тъй като суфиксът се приема за „одомашнен”. В този смисъл може да се твърди, че образуването на такъв модел субстантиви е проява на тенденция към автохтонизация.

\section{Литература}

Аврамова Ц., 2013, Словообразувателни тендениии при съществителните имена в българския и чешкия език в края на ХХ век, София, 259 с.

Андрейчин Л., 1944, Основна българска граматика, София.

Балтова Ю., 1978, За словообразувателната и лексикалната семантика на някои видове nomina agentis в СБЕ (с оглед на представянето им в тәлковен речник), [b:] Славистичен сборник, София, с. 129-135.

Балтова Ю., 2007, Словообразувателното значение в лексикографската дефиниция на производната дума, [b:] Л. Крумова-Цветкова, М. Чоролеева, С. Павлова [ред.], Лексикографията и лексикологията в съвременния свят. Материали от IV национална конферениия с международно участие на Българското лексикографско дружество в чест на проф. Кристалина Чолакова, София, 21-22 октомври 2006, Велико Търново, с. 93-99.

Георгиева Ц., 2012a, Словообразуване по инициални абревиатури I. (част първа), [b:] „Български език”, кн. 4, с. 29-42.

Георгиева Ц., 2012б, За гербера и герберите, [b:] Езикът във времето и пространството (под печат).

Геров Н., I, Речникъ на блъгарскый языкъ А-Д, ч. І, Пловдив 1895, 440 с.

Геров Н., II, Речникъ на блбгарскый языкъ Е-К, ч. II. Пловдив 1897, 450 с.

Геров Н., III, Речникъ на блъгарскый языкъ Л-О, ч. III, Пловдив 1899, 396 с.

Геров Н., IV, Речникъ на блбгарскый языкъ П-Я, ч. IV, Пловдив 1901, 638 с.

Граматика: Ц. Карастанева, В. Маровска [ред.], Граматика на съвременния български книжовен език, т. 2. Морфология, София 1983, 512 с. 
Кювлиева В., 1980, Морфологична адаптачия и асимилачия на турските заемки - съществителни и прилагателни - в българския език, Известия на ИБЕ, XXIV, 1980, с. 78-136.

Радева В., 1991, Словообразуването в българския книжовен език, София, 226 с.

РНД: Ем. Пернишка, Д. Благоева, С. Колковска, Речник на новите думи и значения в българския език, София 2001, 312 с.

РНД: Ем. Пернишка, Д. Благоева, С. Колковска, Речник на новите думи в българския език, София 2010, 520 с.

РЧД: Ст. Буров, П. Пехливанова, Речник на чуждите думи в български с илюстрации, Велико Търново 1995, 768 с.

БСРЛ: Хр. Холиолчев, М. Младенов, Л. Радева, Българска семейно-родова лексика. Енииклопедччен речник, София 2012, 776 с.

\section{Neologisms with suffix -[а]джий(a) in Bulgarian}

\section{Summary}

The article examines the Bulgarian neologisms with suffix -[а]джий(a) in the end of the $20^{\text {th }}$ century and the beginning of the $21^{\text {st }}$ century. The study is carried out on a material from two Bulgarian dictionaries of neologisms. The trend to nationalization is one of the leadings trends in Bulgarian.

Keywords: neologisms; names of persons; Bulgarian language; suffix -[а]джий(a); trends

\section{Neologizmy z przyrostkiem -[a]джuй(a) w języku bułgarskim}

\section{Streszczenie}

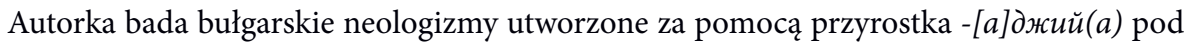
koniec XX oraz na początku XXI wieku. Podstawę studium stanowi materiał z dwóch słowników neologizmów w języku bułgarskim. Tendencja do nacjonalizacji jest jedną $\mathrm{z}$ naczelnych tendencji w języku bułgarskim.

Słowa kluczowe: neologizmy; nazwy osób; język bułgarski; sufiks -[а]джий(a); tendencje 